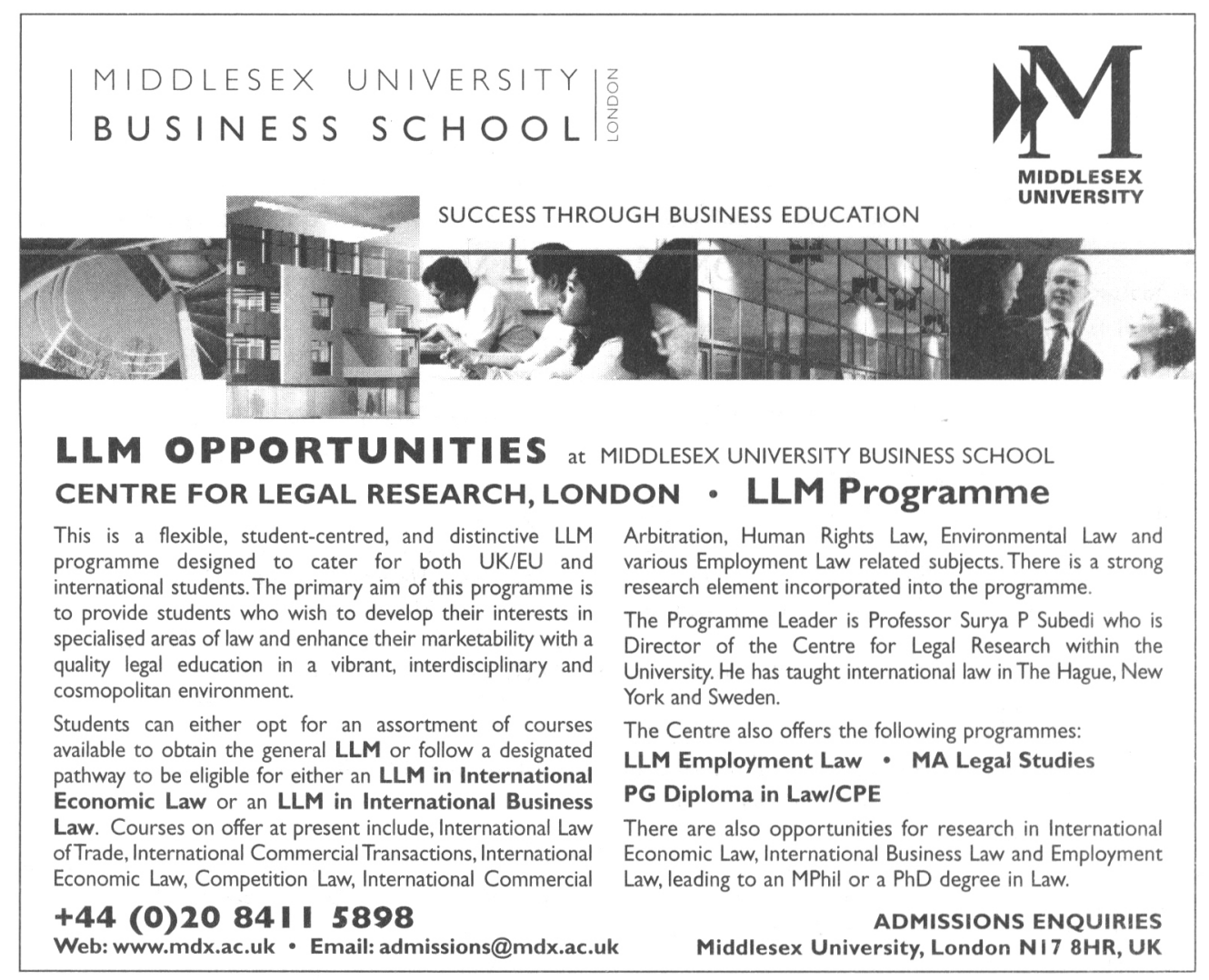

\title{
Postgraduate Legal Education
}

The practice of law in Asia is

undergoing a significant transformation.

Lawyers need to prepare themselves for this change. The School of Law at City University of Hong Kong has the right programme to prepare you for your future. The recently inaugurated Global Gateway programme provides opportunities for international study exchanges throughout the world.

\section{For further information,} please contact Iwgo@cityu.edu.hk or phone (852) 2788-8008 or see www.cityu.edu.hk/slw

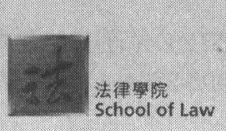

\section{Taught}

LLM

$\frac{2}{2}$

LLM (Chinese and Comparative Law)

LLM (International Business Law)

LLM (WTO and Law)

LLM (Common Law)

LLM in Chinese and Comparative Law (Regular Mode)

[taught predominantly in Chinese (Putonghua)] LLM (Renmin University) [taught in Putonghua]

MA in Arbitration and Dispute Resolution

Postgraduate Diploma in Arbitration and Dispute Resolution Postgraduate Certificate in Laws

\section{- Research}

$\mathrm{PhD}$ in Law

MPhil in Law

Applications for September 2003 available at www.cityu.edu.hk/prospectus. 


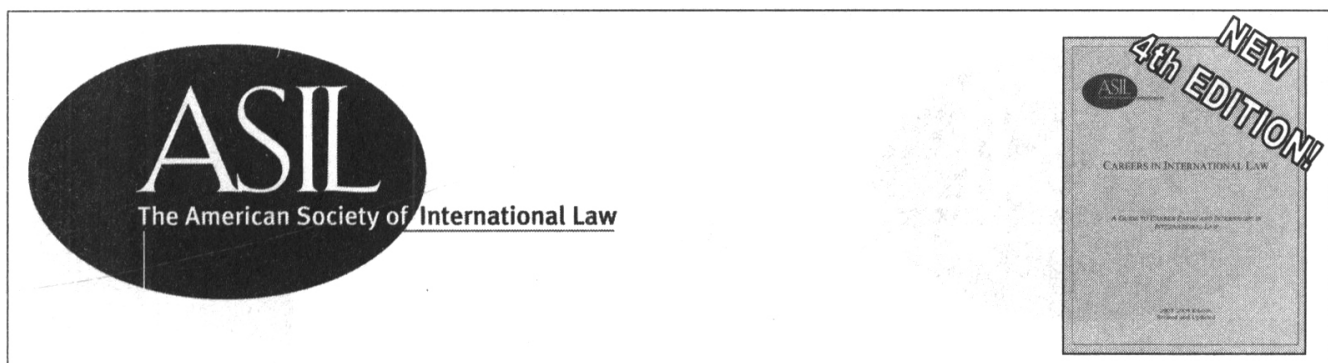

\section{CAREERS IN INTERNATIONAL LAW: A GUIDE TO CAREER PATHS AND INTERNSHIPS IN INTERNATIONAL LAW}

Revised and updated, this $4^{\text {th }}$ edition of Careers in International Law is a valuable resource for any student considering a career in international law. The Guide features descriptions of sixty organizations that offer internships to students with an interest in international law or international relations. It also contains twenty essays in which professionals in areas such as human rights, transactions, and legal education offer advice and share their experiences.

2003-2004 edition \$15 (\$20 for nonmembers)

\begin{tabular}{|l|c|c|}
\hline Title & Qty & Amount $^{*}$ \\
\hline Careers in International Law & & \\
\hline & Subtotal & \\
\cline { 3 - 3 } & DC Residents-add 5.75\% tax & \\
\cline { 3 - 3 } & TOTAL & \\
\hline
\end{tabular}

*Shipping \& handling included.

Are you a member of the ASIL? $\square$ Yes, ID number: No

Name:

Company:

Address:

Country:

Phone: Fax:

E-mail:

Payment: $\square$ Check payable to ASIL (must be drawn in US funds on a US bank) $\square$ Visa $\square$ MasterCard $\square$ American Express

Name:

Number: Expiration:

Signature:

Fax credit card to: (202) 797-7133 Mail to: ASIL, P.O. Box 0164, Washington, DC 20055-0164 USA Call: (202) 939-6000 


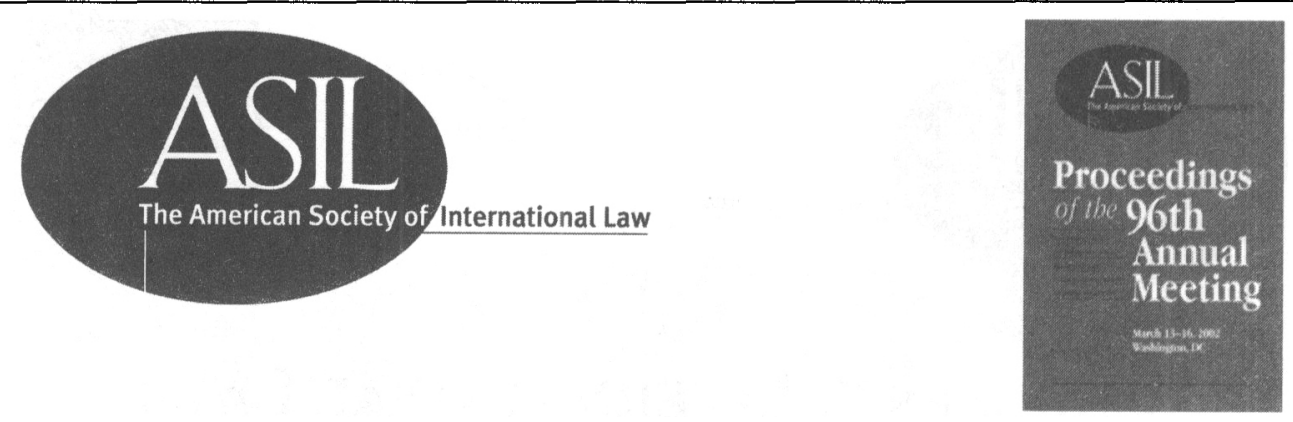

\section{ONE OF THE YEAR'S BEST RECORDS}

The Proceedings is the record of the most important gathering in international law - the ASIL Annual Meeting. Order and receive:

- Insights on current issues and debates in international law.

- The latest research and commentary by leading academics and practitioners from around the world.

- A handy "who's who" of people working in your field.

- An archival record of the continuing growth of international law.

Subscribe today! Visit the ASIL's Web site at $<$ www.asil.org $>$ to learn more about and sign up to receive the Proceedings. 


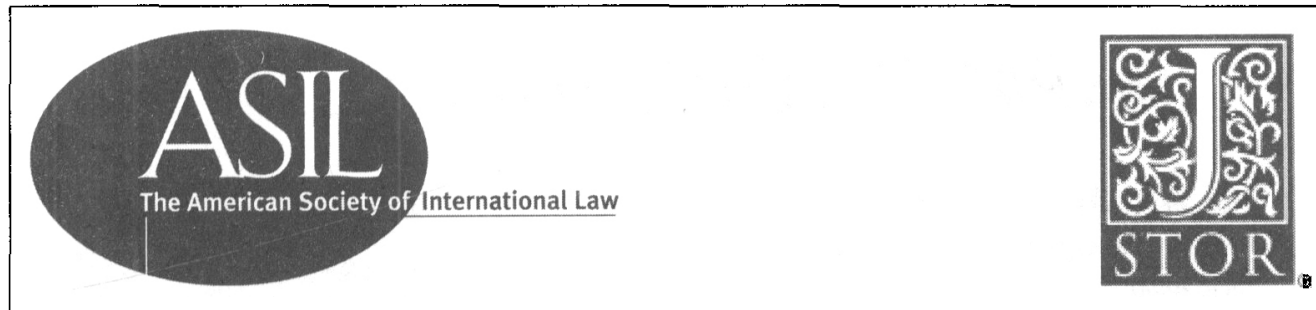

\section{THE AMERICAN JOURNAL OF INTERNATIONAL LAW (1907-Present)}

\section{ONLINE}

The foremost international law scholars and practitioners of the last century are just a click away. Through a special arrangement with JSTOR - an internet-accessible database consisting of the top journals in such fields as history and political science -97 years of the American Journal of International Law are now available online to members of The American Society of International Law.

ASIL MEMBERS SIGN UP FOR ACCESS THROUGH DECEMBER 31, 2003 FOR ONLY \$35!

Member ID Number:

Name:

Address:

Country:

Phone:

Fax:

E-mail:

Payment: $\square$ Check payable to ASIL (must be drawn in US funds on a US bank)

$\square$ Visa $\square$ MasterCard $\square$ American Express

Name:

Number:

Expiration:

Signature:

Fax credit card to: (202) 797-7133 Mail check to: ASIL, P.O. Box 0164, Washington, DC 20055-0164 USA Call: (202) 939-6000 


\section{EXPAND YOUR PERSPECTIVE}

The Health of Nations

Society and Law beyond the State

Philip Allott

0-521-81655-6 Hardback \$75.00

0-521-01680-0 Paperback \$27.00

\section{The Commercial Appropriation of Personality}

Huw Beverley-Smith

Cambridge Studies in Intellectual Property Rights 4

0-521-80014-5 Hardback \$75.00

\section{Forthcoming...}

\section{Pure Economic Loss in Europe}

Edited by Mauro Bussani and Vernon Palmer

Cambridge Studies in International and Comparative Law 28

0-521-82464-8 Hardback $\$ 90.00^{*}$

\section{United States Hegemony and the} Foundations of International Law

Edited by Michael Byers and Georg Nolte

0-521-81949-0 Hardback \$70.00*

The Law of Treaties in Russia and the Commonwealth of Independent States William E. Butler

0-521-81606-8 Hardback $\$ 100.00$

\section{China and the World Trading System}

Entering the New Millennium

Edited by Deborah Z. Cass, Brett Gerard Williams, and George Barker

0-521-81821-4 Hardback \$75.00*

\section{European Criminal Procedures}

Edited by Mireille Delmas-Marty and John Spencer Cambridge Studies in International and Comparative Law 25 0-521-59110-4 Hardback $\$ 140.00$

\section{Corporate Insolvency Law}

Perspectives and Principles

Vanessa Finch

0-521-62256-5 Hardback $\$ 130.00$

0-521-62685-4 Paperback $\$ 47.00$

\section{Recourse to Force}

State Action Against Threats and Armed Attacks

Thomas M. Franck

Hersch Lauterpacht Memorial Lectures 15

0-521-82013-8 Hardback $\$ 55.00$

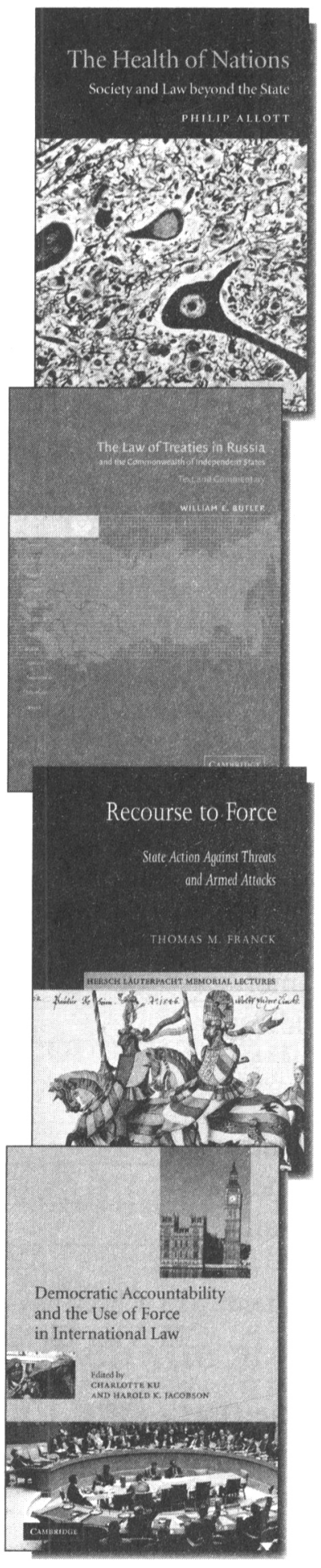




\section{WITH CAMBRIDGE BOOKS}

Democratic Accountability and the Use of Force in International Law

Edited by Charlotte $\mathrm{Ku}$ and Harold K. Jacobson

0-521-80747-6 Hardback \$85.00

0-521-00207-9 Paperback $\$ 30.00$

\section{A World Without Walls}

Freedom, Development, Free Trade

and Global Governance

Mike Moore

0-521-82701-9 Hardback \$28.00

United States Practice in International Law, Volume 1: 1999-2001

Sean D. Murphy

0-521-75070-9 Hardback $\$ 90.00$

\section{The Abolition of the Death Penalty} in International Law

Third Edition

William A. Schabas

0-521-81491-X Hardback $\$ 110.00$

0-521-89344-5 Paperback $\$ 43.00$

\section{Comparative Foundations of a}

European Law of Set-Off and Prescription

Reinhard Zimmermann

0-521-81461-8 Hardback $\$ 55.00$

Now available through

Cambridge University Press...

The Leiden Journal of International Law

Print ISSN: 0922-1565

E-ISSN: 1478-9698

Institutions print plus electronic: $\$ 171.00$

Institutions electronic only: $\$ 143.00$

Individuals print only: $\$ 45.00$

Students print only: $\$ 38.00$

*Prices subject to change.

Available in bookstores or from

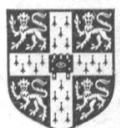

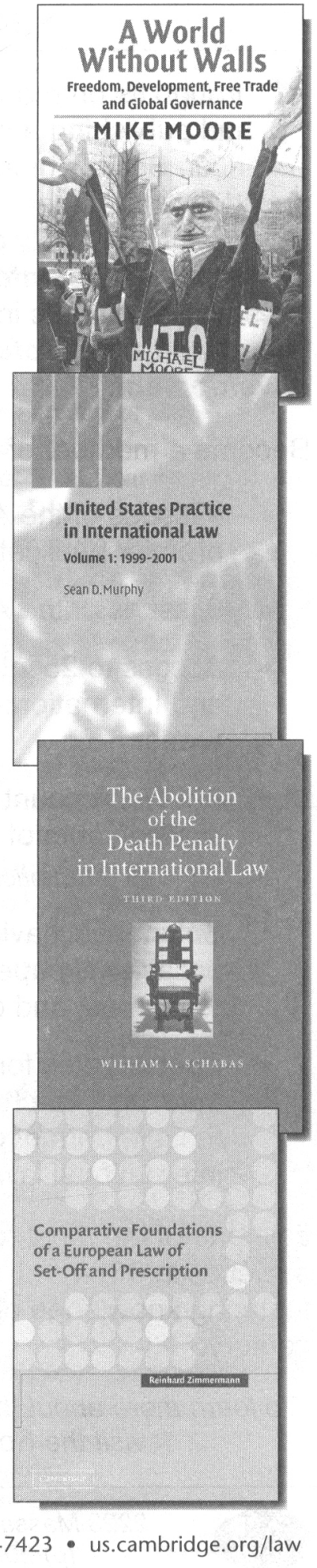




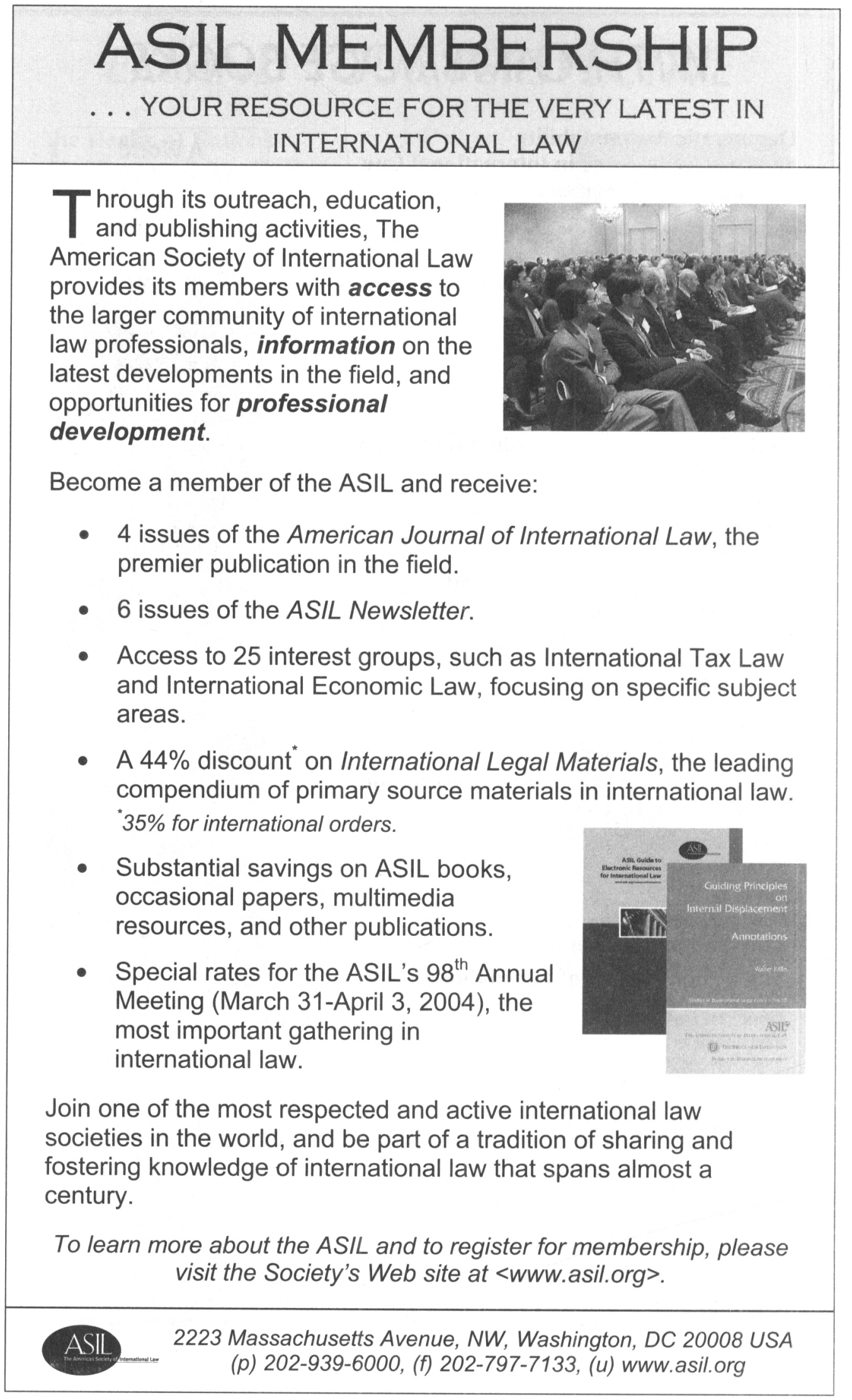




\section{United Nations Publications}

\section{Human Rights for All}

×The Human Rights of Migrants

With international migration at an all time high, government officials, policy makers, NGOs, researchers and international agencies have only begun to consider the human rights dimension. This collection of articles summarizes main trends, issues, debates, actors and initiatives currently conditioning the recognition and extension of protection of human rights of migrants.

E.01.III.S.1 9290681055 152pp. $\$ 18.00$

×Notable Government Documents Award Winner!

Human Rights and Disability: The Current Use and Future Potential of United Nations Human Rights Instruments in the Context of Disability

The world has seen a shift in perspective over the past two decades, from viewing people with disabilities as problems, towards viewing them as holders of rights. The study analyzes this development in three parts. The first part covers the nature of the shift to the human rights framework in the context of disability. The second part is an evaluation of the current use of the United Nations human rights instruments, providing a detailed analysis of the actual and potential relevance of each of the human rights treaties in the context of disability. The final part outlines options for the future. E.02.XIV.6 9211541468 196pp. $\$ 32.00$

Implementation Handbook for the Convention on the Rights of the Child

This Handbook is a practical tool for all those involved in implementing the principles and provisions of the Convention and realizing the human rights of children. Under each article of the Convention, the Handbook records and analyzes the interpretation by the Committee on the Rights of the Child, the internationally elected body of independent experts established to monitor progress worldwide. It includes the two Optional Protocols to the Convention, and their guidelines for reporting, as well as other new international instruments aimed at promotion and protection of children's rights.

E.02.XX.6 $9280637822 \quad 782 p p . \quad \$ 50.00$

Trafficking in Women and Prostitution in the Baltic States: Social and Legal Aspects Trafficking in human beings has become a serious global concern. This report provides a summary of current international instruments that relate to trafficking and deal with the particular problems of trafficking in the Baltic States - Estonia, Latvia and Lithuania. In addition to drawing from national data about the Baltic States, the report also selectively considers the law and practice of some EU member states. The publication looks at the treatment of trafficking victims and covers preventive measures.

E.02.II.S.6 9290681179 352pp. $\$ 32.00$

United Nations Publications, Department of Public Information (DPI)

Sales and Marketing Section, Room DC2-0853, Dept.A406, New York, NY 10017

Tel. (800) 253-9646, (212) 963-8302 Fax. (212) 963-3489

E-Mail: publications@un.org Internet: http://www.un.org/publications VISA, MC and AMEX accepted. 


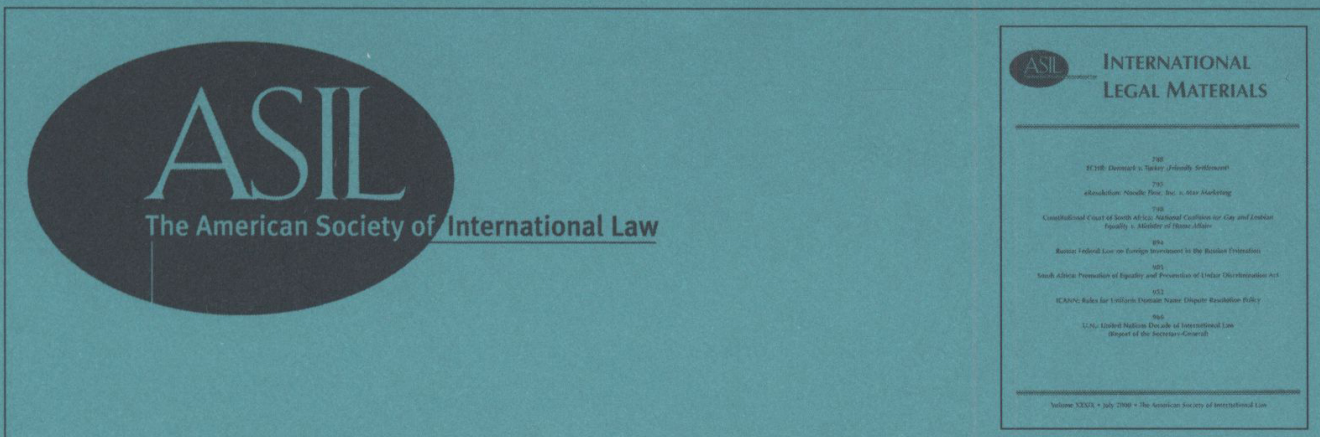

\section{PROBLeM SOlVED.}

Subscribe to International Legal Materials, and solve a few modern problems:

$>$ Web sites come and go, taking the usefulness of your citations with them.

$>$ Most libraries are not repositories of U.N. Treaties and arbitral decisions.

$>$ You cannot write notes in the margins on your computer screen.

$>$ Information is not at your fingertips when Internet searches yield 2,349 results.

Visit the ASIL Web site at <www.asil.org>, sign up for $I L M$ in 2003, and relax.

...problem solved.

The American Society of International Law, 2223 Massachusetts Avenue, NW, Washington, DC 20008, (p) 202-939-6000, (f) 202-797-7133, (u) www.asil.org 